\title{
Students' perceptions of classroom justice and their use of politeness strategies
}

\author{
Charles K. Rudick \\ West Virginia University
}

Follow this and additional works at: https://researchrepository.wvu.edu/etd

\section{Recommended Citation}

Rudick, Charles K., "Students' perceptions of classroom justice and their use of politeness strategies" (2010). Graduate Theses, Dissertations, and Problem Reports. 711.

https://researchrepository.wvu.edu/etd/711

This Thesis is protected by copyright and/or related rights. It has been brought to you by the The Research Repository @ WVU with permission from the rights-holder(s). You are free to use this Thesis in any way that is permitted by the copyright and related rights legislation that applies to your use. For other uses you must obtain permission from the rights-holder(s) directly, unless additional rights are indicated by a Creative Commons license in the record and/ or on the work itself. This Thesis has been accepted for inclusion in WVU Graduate Theses, Dissertations, and Problem Reports collection by an authorized administrator of The Research Repository @ WVU. For more information, please contact researchrepository@mail.wvu.edu. 
Students' Perceptions of Classroom Justice and their use of Politeness Strategies

\author{
Charles K. Rudick
}

\author{
Thesis submitted to the \\ Eberly College of Arts and Sciences \\ at West Virginia University \\ in partial fulfillment of the requirements \\ for the degree of \\ Master of Arts \\ in \\ Communication Theory and Research \\ Scott A. Myers Ph.D., Chair \\ Megan R. Dillow, Ph.D. \\ Christine E. Rittenour, Ph.D. \\ Department of Communication Studies
}

Morgantown, West Virginia

2010

Keywords: Politeness, Facework, Classroom Justice 


\begin{abstract}
The Relationship between Students' Politeness Strategies and Students' Perceptions of Classroom Justice
\end{abstract}

\title{
Charles K. Rudick
}

The purpose of this study was to investigate how students' use of politeness strategies differed based on their perceptions of distributive, procedural, and interactional justice when they engaged in a face threatening act (FTA) with their instructors. Participants included 76 undergraduate students enrolled in undergraduate communication courses at a large midAtlantic university during the summer. Results revealed that students engage in all types of politeness strategies when speaking with their instructor, with students reporting the bald-onrecord strategy the most frequently. However, students' use of politeness strategies did not significantly differ based on their perceptions of distributive, procedural, and interactional justice. Implications, limitations, and future research are discussed. 


\section{ACKNOWLEDGEMENTS}

I would like to thank Dr. Scott A. Myers, the chair of my thesis committee for his seemingly never-ending supply of patience when working on this project with me. I also would like to thank Dr. Megan Dillow for her clear comments and helpful feedback, especially concerning politeness theory. Finally, I would like to thank Dr. Rittenour for her enthusiasm and her insights when changing the methodology. 


\section{TABLE OF CONTENTS}

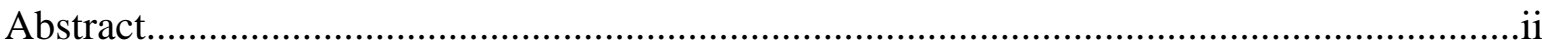

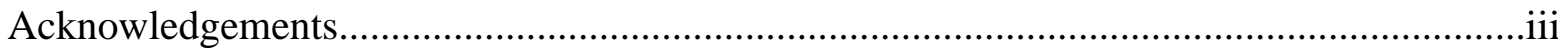

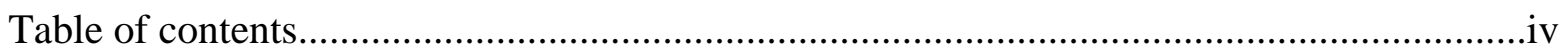

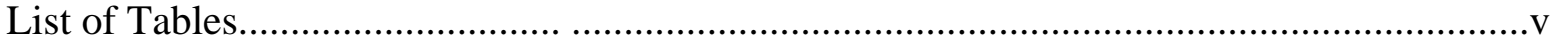

Chapter 1- Literature Review.............................................................................1-17

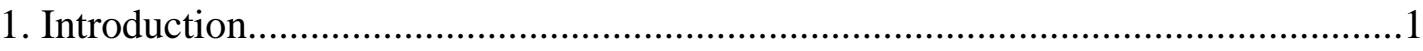

2. Politeness Theory...................................................................................2-10

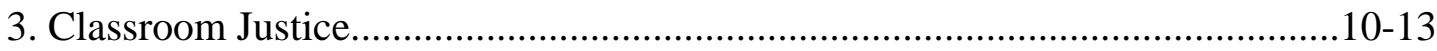

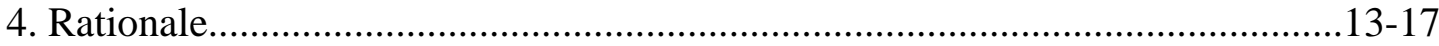

Chapter 2- Method............................................................................................ 18-22

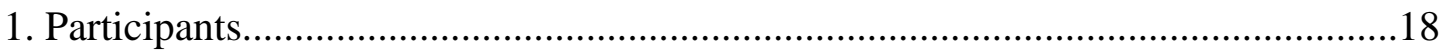

2. Procedure/Instrumentation............................................................... 18-20

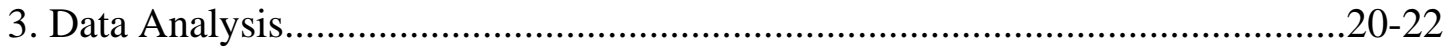

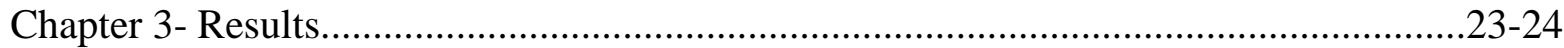

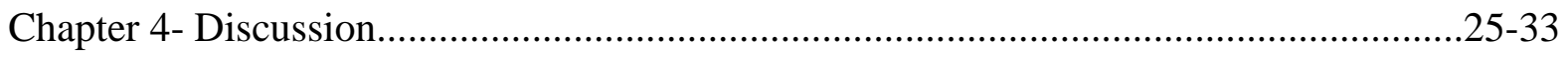

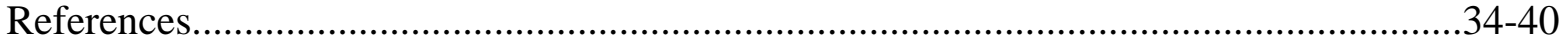

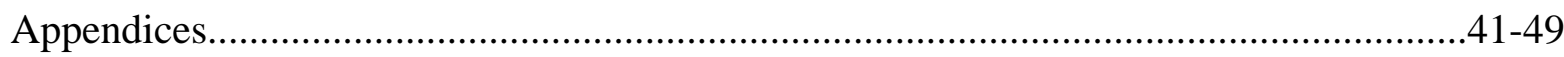

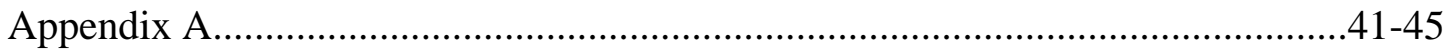

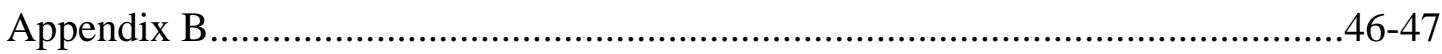

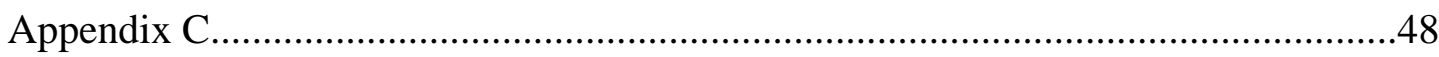

Appendix D....................................................... 49-50 


\section{CHAPTER ONE}

\section{Introduction}

Politeness theory (Brown \& Levinson, 1978; 1987) has been a dominant theory in sociological and communication research over the past 20 years and has been used to examine affectionate expressions (Erbert \& Floyd, 2004), compliance gaining (Wilson, Aleman, \& Leatham, 1998), and giving advice (Goldsmith, 1999). Recently, investigations of instructional communication have utilized politeness theory to examine how instructors and students negotiate multiple task and relational goals in the classroom (Kerssen-Griep, Trees, \& Hess, 2008; Kerssen-Griep, Hess, \& Trees, 2003; Trees, Kerssen-Griep, \& Hess, 2009). Although the findings from such research are important, investigations focusing on the students' communicative behaviors have been largely overlooked. How students communicate with their instructors' is an important facet of the classroom dynamic that warrants exploration, as these interactions may influence students' performance in class.

This study furthers inquiries into politeness in the classroom by examining how students' use of politeness strategies differ based on their perceptions of instructors' classroom justice when speaking with their instructors. Classroom justice has been found to relate to many student outcomes, yet has been a relatively untapped avenue of research since its inception (Chory-Assad, 2002). The first section of the review of literature focuses on politeness theory, and identifies the five strategies that comprise the first set of variables (i.e., bald-on-record, positive politeness, negative politeness, off-the-record, and forego-the-FTA). The second section examines the second set of variables, which are students' perceptions of classroom justice (i.e., distributive, procedural, and interactional). 


\section{Politeness Theory}

Politeness theory (Brown \& Levinson, 1978; 1987) explains how individuals negotiate relationships with one another while pursuing goals. Politeness theory is based on the concept of face, which was first advanced by Goffman (1967) in his influential essay On Facework. He conceptualized face as the positive self-image that an individual wants to portray. Politeness theory is also informed by Grice's (1989) four maxims of the cooperative principle. The cooperative principle is the obligation that individuals have to speak as required, which is determined by fulfilling the four maxims of conversation which are: quantity, which is to not communicate more or less information than is required; quality, which is to not give false information or information that is unsubstantiated; relation, which is to say what is relevant to the topic at hand; and manner, which is to avoid purposeful ambiguity and to be brief and orderly in giving information. These maxims are the guidelines for the most efficient ways to communicate between individuals. Brown and Levinson (1987) state that the reason for not carrying out the cooperative principle in communication is politeness. Politeness, they state, is a deviation from efficiency and is how individuals communicate attentiveness to another individual's face needs.

Brown and Levinson (1987) extended Goffman's original conceptualization of face by stating that face is "the public self-image every member wants to claim for himself [sic]" (p. 61). In politeness theory, Brown and Levinson proposed two types of face: positive face, which is the need for solidarity, and negative face, which is the need for autonomy. Positive face is maintained when individuals perceive that their behaviors are approved by another individual, whereas negative face is maintained when individuals are able to preserve their freedom of action. When individuals behave in ways that attempt to be consistent with the 
self-image they wish to portray, they are engaging in facework (Goffman, 1967). Individuals have two orientations in facework, a defensive orientation (i.e., the desire of an individual to maintain their own face) and a protective orientation (i.e., the desire of an individual to maintain another's face). When individuals engage in protective facework, they do so through politeness strategies.

Lim and Bowers (1991) later argued that this dichotomous concept of face was inadequate and proposed that face was comprised of three types: solidarity, approbation, and tact. They stated that positive face should be divided into two types: solidarity, which is the need for the approval of others, and approbation, which is the need to be viewed as competent by others. The third type of face, tact, is the same as Brown and Levinson's (1987) conceptualization of negative face.

Some interpersonal scholars (e.g., Tracy \& Tracy, 1998) have argued that Goffman's (1967) single-facet conceptualization of face captures the fluidity of social interaction better than two or three type conceptualizations because conceptualizations of multiple types of face place researchers' focus on effectively distinguishing which type of face the speaker attending to, rather than on the face that is at stake in the interaction. Tracy \& Tracy (1998) state that the focus of Brown \& Levinson's $(1978 ; 1987)$ politeness theory has overlooked Goffman's (1967) aggressive facework (i.e., when individuals attempt to enhance their own face at another's expense) and makes investigations concerning face-attacks (i.e., purposefully offensive communication) impossible. Although a promising area of study, because the purpose of this study was not to examine face-attacks, the single-facet conceptualization was not used. In instructional communication literature, Brown and Levinson's (1987) and Lim and Bowers (1991) conceptualizations of face have been the 
most utilized. However, the most recent research by Kerssen-Griep et al. (2008) utilized Brown and Levinson's (1987) conceptualization, as students' reports of solidarity and approbation have shown no predictive difference (Kerssen-Griep et al., 2003).

Behaviors that threaten the desired self-image of an individual (i.e., an individual's face) are face-threatening acts (FTAs). Brown and Levinson (1987) stated that FTAs either threaten the solidarity shared between individuals (i.e., a threat to positive face) or constrain autonomy (i.e., a threat to negative face). Although politeness theory holds that FTAs threaten either positive or negative face, research investigating affectionate communication between friends (Erbert \& Floyd, 2004) and compliance gaining between same-sex friends (Wilson et al., 1998) demonstrates that both types of face can be threatened simultaneously. FTAs perceived seriousness is influenced by three types of variables: social distance, which is based on perceived closeness or familiarity, power, which is the extent to which an individual can influence another's actions, and rank order of imposition, which is the degree to which the threat constrains an individual's wants (Brown \& Levinson, 1987).

According to Goffman (1967), individuals are generally expected to attempt (to the extent dictated by their culture) to mitigate the threat to face of others in social interactions. Brown and Levinson (1987) stated that individuals take three wants into consideration before engaging in facework. These considerations include the weighing of: (a) how much the individual wants to communicate the message, (b) the want or need to be efficient, and (c) the desire to maintain the receiver's face. They posited that as long as the desire for (c) is greater than the want or need for (b) then an individual will attempt to minimize the threat of a FTA for another. They go on to offer five superordinate strategies that individuals can perform to mitigate face threat. 
These five strategies, which are listed hierarchally from least to most polite, or the extent to which they mitigate the FTA, include bald-on-record, positive politeness, negative politeness, off-record, and forego the FTA. A bald-on-record strategy is one that is direct, clear, and unambiguous (e.g., Your performance is unacceptable). Individuals who utilize the bald-on-record strategy usually do so because they believe that face concerns are irrelevant or that efficiency is more important than facework. Although this strategy is the least polite, the use of this strategy may be construed as positive by receivers as bald-onrecord strategies are may be perceived as the senders' attempt to be clear or honest. Brown and Levinson (1987) claim the bald-on-record strategy mirrors Grice's (1989) cooperative principle, in that senders make no effort to attend to the receivers' face. Instead, senders attempt to maximize the efficiency of the conversation by being as direct and unambiguous as possible.

Positive politeness is a strategy used to reduce the threat to positive face by giving the sense that the sender has the receiver's best interests at heart (e.g., You are really talented, but that was not your best work). The sender can do this either by identifying common ground shared with the receiver or by indicating that both parties have mutual interest in reaching a goal. Brown and Levinson (1987) state that positive politeness is senders' attempt to communicate intimacy with receivers, violating Grice's (1987) maxims of quantity, relation, and manner. Negative politeness is a strategy intended to affirm the receiver's autonomy. The use of this strategy attempts to communicate that the sender's wants do not infringe on the receiver by creating psychological or physical space so the receiver does not feel threatened (e.g., Your performance just needs a little more work). As Brown and Levinson (1987) point out, negative politeness strategies include methods such as being 
conventionally indirect, hedging, and questioning, violating Grice's maxims of quantity, relation, and manner. Because senders make their request first and then engage in positive and negative politeness strategies, the two strategies are used to balance the competing needs of efficiency and politeness. The senders' chosen strategy violates Grice's quantity, relevance, and manner maxims, they still seek to "get the point across" to receivers.

Off-record is a strategy that is purposely ambiguous so that receivers are unable to hold senders to implied commitments. For example, instructors might ask "Did you stay up late last night" to students who fall asleep in class. This strategy can be beneficial as the sender can usually claim miscommunication if the receiver becomes offended by the statement's implication. However, this strategy also may be viewed as manipulative by the receiver because of its intentional ambiguity. Forego-the-FTA is to not engage in the communicative act that may threaten the receiver's face. This strategy is used when the perceived benefits of the FTA are outweighed by the perceived costs of initiating the FTA. Although this strategy is the most polite, it rarely ends in the attainment of the sender's goal as it is extremely difficult for receivers to recognize that senders are attempting to communicate a need. Senders who choose off-record or forego-the-FTA strategies directly violate Grice's (1989) manner maxim, as they are more concerned with the face needs of receivers than conveying the information efficiently.

Research has found mixed support concerning the hierarchal ranking of the five politeness strategies, with research indicating that individuals' rating of positive and negative politeness strategies (Baxter, 1983) and negative politeness and off-record strategies (Holtgraves \& Joong-nam, 1990) trade places with each other in Brown and Levinson's (1987) posited order. This may be due to individuals' social or cultural expectation for 
senders to attend to one type of face over another in certain situations (e.g., giving advice), which would make it more likely that individuals would report different rankings to the order of politeness strategies (Goldsmith, 1999). However, in their investigation of affectionate communication, Erbert and Floyd (2004) found support for the posited order, indicating support for the use of Brown and Levinson's (1987) hierarchal ranking of politeness strategies.

In the instructional communication context, research using politeness theory has been confined largely to students' perceptions of instructors in feedback exchanges (i.e., communication regarding students' performance in regard to the classroom; Kerssen-Griep et al., 2003; Kerssen-Griep et al., 2008; Sabee \& Wilson, 2005; Trees et al., 2009). One exception to this line of research is the use of politeness theory to investigate students' nagging behaviors with their instructors (Dunleavy et al., 2008). Nagging behaviors are defined as "persistent, non-aggressive requests which contain the same content to a respondent who fails to comply" (p. 2). Dunleavy et al. (2008) found that students' use of nagging behaviors harmed instructors' and students' positive and negative face. Specifically, the flatter the instructor nagging behavior and the demonstrate frustration with the instructor nagging behaviors were the most threatening to instructors' negative and positive face respectively. They also found that the strike a deal nagging behavior and elicit sympathy nagging behavior were the most threatening to students' negative and positive face respectively. Additionally, they demonstrated that students used increasingly polite strategies when they believed their nagging behaviors were likely to harm their instructors' positive face. 
Although nagging behaviors can be enacted in reference to feedback exchanges, not all feedback exchanges are characterized by nagging behaviors. In their investigation of the primary goals that students exhibit when communicating in a feedback exchange with their instructor, Sabee and Wilson (2005) identified four primary goals that students have when they communicate in feedback exchanges. The first goal is learning, which occurs when students view the feedback exchange as an opportunity for intellectual growth. The second goal is persuading, which is characterized by students communicating with their instructors about feedback in the hope that they can persuade their instructors to give them a better grade. The third goal is fighting, which is when students communicate aggressively with their instructor about their received feedback with the aggressive communication as the means and goal of students' communication. The fourth goal is impressing, which is defined as when students engage in feedback with the intention of "scoring points" with their instructors.

Kerssen-Griep and colleagues continued to investigate facework in instructional feedback situations. Kerssen-Griep et al. (2003) found that students' perception of instructors' attention to solidarity during feedback exchanges was the most consistent predictor of all but one classroom outcome (i.e., work avoidance). These outcomes are students' evaluations of knowledge gained, evaluations of accomplishing objectives, evaluations of amotivation, attentiveness, responsiveness, and alliance with a task mastery approach to succeeding in school. They suggested that solidarity may be such an important component of classroom interaction either because of its close relation to perceived instructor immediacy, which has been shown to enhance learning outcomes (Anderson, 
1979), or because perceived instructor solidarity encourages a relationship based on mutual respect in problem solving endeavors in the classroom.

Subsequent research about skilled facework in instructional feedback exchanges was conducted by Kerssen-Griep et al. (2008) and Trees et al. (2009). Instructors who use skillful facework are able to successfully negotiate two competing goals: to correct students' performance (i.e., a task goal) and to protect students' identity (i.e., a social goal) when engaging in facework (Trees et al., 2009). Kerssen-Griep et al. (2008) found students' reports of instructors' use of skillful facework predicted students' perceptions of being psychosocially mentored as well as students' perceptions of their satisfaction with mentoring. Trees et al. (2009) reported that skillful facework during feedback influences students' perceptions of instructor feedback and perceived instructor credibility. They found that students perceived feedback to be more useful and fair when they perceived their instructor to be attentive to their face needs. They also reported feeling less defensive during feedback when their instructor displayed attentive facework. Additionally, students' perceptions of skillful facework were associated with higher perceptions of instructor competence and character.

As investigations using politeness theory in instructional contexts demonstrate, facework in the classroom influences a wide range of instructional outcomes. An underrepresented area of focus in research to date is investigations of students' use of politeness strategies with their instructors. One area in which politeness theory may be fruitfully applied is the context of students' perceptions of classroom justice (Chory-Assad, 2002). This study will investigate how students' use of politeness strategies differ based on 
their perceptions of instructors' distributive, procedural, and interactional justice when engaging in an FTA with their instructor.

\section{Classroom Justice}

Drawing upon organizational literature concerning justice (Cropanzano \& Greenberg, 1997), Chory-Assad and Paulsel (2004a) defined classroom justice as students' perceptions of fairness regarding the outcomes or processes that occur in the classroom. Chory-Assad (2002; Chory-Assad \& Paulsel, 2004a) conceptualized classroom justice as three dimensional, including: distributive, procedural, and interactional justice. Distributive justice refers to students' perceptions that outcomes (e.g., grades) are fairly dispensed by the instructor (Tata, 1999), procedural justice refers to students' perceptions that the policies (e.g., the course syllabus) that the instructor uses are fair (Thibaut \& Walker, 1975), and interactional justice refers to students' perceptions that they are treated fairly in interpersonal exchanges with the instructor (Bies \& Moag, 1986). Research conducted by Colquit (2001) suggested that interactional justice should be divided into two types of justice: interpersonal (i.e., respect for the student) and informational (i.e., students' perceptions that they received adequate information from the instructor). Results of the confirmatory factor analysis revealed that the four dimensional model provided the best fit for the data. Citing Colquitt's (2001) study, Chory (2007) revised the scale of interactional justice, but did not divide the measurement into the two types. Results of the confirmatory factor analysis revealed that the three dimensions of classroom justice were unidimensional. The present study utilizes the three types of justice used by Chory-Assad and her colleagues as research in instructional communication research has demonstrated its validity in assessing their influence on classroom outcomes. 
Research concerning classroom justice and its effect in the classroom has demonstrated that students' perceptions of instructor fairness plays a major role in their classroom experience. Early studies investigating classroom justice focused solely on procedural and distributive justice (Chory-Assad, 2002; Chory-Assad \& Paulsel, 2004b). The findings of these studies indicted that procedural justice and distributive justice were associated positively with student state motivation and affective learning (Chory-Assad, 2002). It was also found that students who perceived less procedural justice reported higher use of indirect interpersonal aggression (i.e., communication intended to harm another without engaging the individual face-to-face), hostility (i.e., primarily direct forms of verbal aggression), and engaged in more student resistance strategies (i.e., behaviors initiated to oppose the instructor) such as student resistance through revenge and deception (ChoryAssad \& Paulsel, 2004b).

Chory-Assad and Paulsel (2004a) investigated the effects of students' perceived interactional justice and found that students' perceptions of instructor interactional justice negatively predicted interpersonal aggressiveness toward the instructor. They also found that instructors' use of antisocial behavior alteration techniques or BATs (i.e., pro- or anti-social resources instructors use to influence students; Plax, Kearney, \& Tucker, 1986) were associated negatively with students' perceptions of instructor interactional justice. Specifically, students perceived the classroom to be unjust when instructors engaged in BATs such as making threats of punishment, making students feel guilty, creating a negative teacher-student relationship, appealing to their own legitimate power, or making students feel like they were indebted to the class. Pausel and Chory-Assad (2005) found that when students perceived that their instructors engaged in less interactional justice, the students 
were more likely to resist using strategies such as giving the teacher advice, blaming the teacher, appealing to those with more authority than the teacher, and modeling the teacher's affect.

Students' perceptions of classroom justice also have been related to students' perceptions of instructors' use of power (i.e., expert, legitimate, coercive, referent, and reward) (Paulsel, Chory-Assad, \& Dunleavy, 2005) and students' perceptions of instructor credibility (Chory, 2007; Teven \& McCroskey, 1997; McCroskey \& Teven, 1999). Paulsel et al. (2005) found that students' perceptions of instructors' use of expert power (i.e., based on students' perception that the instructor is knowledgeable) shared a positive association with distributive, procedural, and interactional justice; referent power (i.e., based on students' desire to identify with their instructor) was associated positively with interactional justice; and legitimate power (i.e., based on students' perception that the instructors' title gives them power) was associated positively with procedural justice. Coercive power (i.e., based on students' perception that the instructor can punish them) was associated negatively with interactional justice. Additionally, Chory (2007) found that students' perceptions of instructors' credibility were associated positively. Specifically, students' perceptions of competence (i.e., being an expert) were associated positively with their perceptions of interactional justice; their perceptions of instructors' character (i.e., trustworthiness) were associated positively with distributive, procedural, and interactional justice; and their perception of instructors' caring (i.e., empathy) was associated positively with procedural and interactional justice.

Horan and Myers (2009) sought to extend research investigating classroom justice by examining how instructors perceived classroom justice. They found that instructors are most 
concerned with interactional justice, followed by procedural justice and distributive justice. Additionally, the findings of the study indicated that instructors' concern for the procedural and interactional justice demonstrated a negative relationship with antisocial BATs. This finding supports research which argues the importance of instructors being able to negotiate the task and social goals in the classroom as they influence the ways classrooms operate (Trees et al., 2009),.

Collectively, these studies indicate that instructors' behaviors and characteristics have a great amount of influence in students' perceptions of classroom justice. Generally, when students perceive less justice, they are more likely to behave negatively and engage in resistance (Chory-Assad, 2002; Chory-Assad \& Paulsel, 2004a; Paulsel \& Chory-Assad, 2005). The tendency of students to use these behaviors has important implications for what type of politeness strategy they employ when interacting with an instructor.

\section{Rationale}

This purpose of this study is to investigate how students' perceptions of distributive, procedural, and interactional justice differ by their use of politeness strategies when engaging in an FTA with their instructor. This study is important for two reasons. First, because the student-instructor relationship can be considered an interpersonal relationship (Frymier \& Houser, 2000; Nussbaum \& Scott, 1979), it is important to know what behaviors can affect the relational process in student-instructor communication. Mottet and Beebe (2006) stated that the relational process is characterized by students' and instructors' mutual communication to develop a relationship with one another. When students and instructors engage in the relational process in communication, they begin to communicate with each other more as individuals and are less bound by their different roles (Dobransky \& Frymier, 
2004). The relational process of communication can be enacted through behaviors such as students' out-of-class communication with their instructors (Dobransky \& Frymier, 2004) or instructors' use of the ego-support functional communication skill (i.e., the ability to make others feel good about themselves) (Frymier \& Houser, 2000). Although not all studentinstructor relationships can be considered interpersonal, knowing how students and instructors negotiate their relationship is important as researchers indicate that students' perception of their instructors as caring and trustworthy exerts a large amount of influence on a myriad of outcomes such as their affective learning, cognitive learning, respect for teachers, perceived understanding, and in-class and out-of-class communication (Finn et al., 2009).

Second, by investigating how students' use of politeness strategies differs by their perceptions of instructors' classroom justice, it will be possible to provide students and instructors practical advice for negotiating justice in the classroom. Instructors who receive less polite forms of communication from their students may wish to review how they negotiate classroom justice. Specifically, instructors may need to focus more on procedural and distributive justice, as instructors rate these two types of justice as less important than interactional justice (Horan \& Myers, 2009). On the other hand, students may need to ask their instructors about the instructors' preferred level of politeness when communicating as well as their perceptions of how they enact classroom justice so students are better prepared to communicate appropriately with their instructors.

A review of the literature does not indicate which type of politeness strategies are the most frequently used by students when they speak with their instructors. Therefore, a preliminary analysis of the frequency of student use of politeness strategies was explored with the following research question: 
RQ1: What, if any, types of politeness strategies do students report using with their instructors?

Students may communicate with their instructors in a less polite manner when they perceive that the outcomes in the classroom (e.g., grades) do not match their expectations. Tata (1999) found that students' who perceived that the grade they received was fair were more likely to rate their instructor higher on instructor evaluations than those students who received grades they perceived as unfair. However, research has not found a relationship between distributive justice and student outcomes such as verbal aggressiveness or hostility (Chory-Assad, 2002; Chory-Assad \& Paulsel, 2004b). This finding suggests that students may be less concerned with distributive justice or may be less willing to challenge instructors who have control over their outcomes in class. As a result, students may be less likely to initiate FTAs or, if they do, would use more polite strategies more so when engaging in an FTA when students speak with their instructor about the perceived fairness of a grade they received. To explore this idea, the following research question is posed:

RQ2: In what ways, if at all, does students' use of politeness strategies when engaging in an FTA with their instructor differ based on their perceptions of distributive justice?

Extant research indicates that when students perceive their instructors' policies or the way that instructors communicate with students to be unfair, students are more likely to be aggressive and hostile (Chory-Assad, 2002; Chory-Assad \& Paulsel, 2004a; Chory-Assad \& Paulsel, 2004b). For procedural justice, this is not surprising because many students view their enrollment in the course from a consumer standpoint (Emanuel \& Adams, 2006; McMillan \& Cheney, 1996; Mottet, Parker-Raley, Cunningham, Beebe, \& Raffeld, 2006). As 
McMillan and Cheney (1996) note, the metaphor of the "student-as-consumer" diverts attention away from the process of education and instead places it on the product (i.e., getting the grades necessary to get a job). In other words, students become aware of the process (i.e., through the course syllabus) when students perceive that the policies inhibit them from succeeding. Students who view themselves as consumers may equate a violation of course policies as a breach of contract, which may lead to the perception that the instructor is being unfair. Therefore, students who engage more frequently using less polite strategies with their instructor may do so because they feel that the instructor's policies do not meet their expectation of fairness.

In terms of interactional justice, students report that they expect instructors to be pleasant, cheerful, friendly, patient, open-minded, and fair (Becker, Davis, Neal, \& Grover, 1990). A violation of this expectation would be an instructor who was highly verbally aggressive. Myers and Rocca (2001) found that students' reports of highly verbally aggressive instructors shared an inverse relationship with their reports of classroom climate and state motivation. Additionally, Kearney, Plax, and Burroughs (1991) found that students are more likely to attribute the reasons for their resistance as instructor-owned when they do not perceive their instructor as immediate. Kearney, Plax, Smith, and Sorensen (1988) found that students were more likely to comply with immediate instructors as opposed to nonimmediate instructors. Together, the findings from these studies suggest that students have an expectation for a congenial and warm instructor and would be more likely to communicate politely when this expectation is met. When an instructor does not display these characteristics, students may mirror instructors' demeanor and communicate less politely.

However, Golish and Olson (2000) stated that students often perceive instructors to 
be in a "one-up" position of power in the classroom, so students may tend to use more polite strategies regardless of their perceptions of instructor unfairness. Goodboy, Myers, and Bolkan (2010) report that when students perceive their instructors as engaging in antisocial communication, they are less motivated to speak with their instructors. These studies make it unclear as to how students' perceptions of procedural or interactional justice may differ based on their use of politeness strategies. Therefore, the following research questions are posed:

RQ3: In what ways, if at all, does students' use of politeness strategies when engaging in an FTA with their instructor differ based on their perceptions of procedural justice?

RQ4: In what ways, if at all, does students' use of politeness strategies when engaging in an FTA with their instructor differ based on their perceptions of interactional justice? 


\section{CHAPTER TWO}

Method

\section{Participants}

Following approval by the Institutional Review Board for the Protection of Human Subjects, recruitment was conducted during the summer intersession in undergraduate communication courses at a large mid-Atlantic university. The participants were volunteer and almost half $(n=34)$ received minimal course credit for participating in the project. The other participants $(n=42)$ did not receive any incentive to participate. To participate, students had to be enrolled currently in the university and be at least 18 years of age.

Participants included 76 students $(N=76)$ whose ages ranged from 19 to 40 years $(M$ $=22.32, S D=3.62)$. The participants' report of ethnicity was $53.9 \%(\mathrm{n}=41)$ of the sample as White/Caucasian, $19.7 \%(\mathrm{n}=15)$ as Middle Eastern, $7.9 \%(\mathrm{n}=6)$ as Black/African American, 6.6\% $(\mathrm{n}=5)$ as Latino/a, 2.6\% $(\mathrm{n}=2)$ as Asian/Eastern Pacific, 1.3\% $(\mathrm{n}=1)$ American Indian, and 2.6\% ( $\mathrm{n}=2)$ as other. Forty-eight participants identified as female and 24 participants identified as male. Participants' reports of year in school were grouped as first year $(n=3)$, sophomore $(n=8)$, junior $(n=26)$, senior $(n=29)$, and other $(n=6)$. Four participants did not report their ethnicity, sex, or year in school.

\section{Procedures and Instruments}

Participants completed two instruments during the first or second week of the intersession, which began two weeks after the spring semester ended. These instruments were the Classroom Justice scale (Chory-Assad \& Paulsel, 2004b; Chory, 2007) and the Likelihood to Use Politeness Strategies scenario developed specifically for this study. The participants were instructed to complete the Classroom Justice scale, read the scenario, and 
complete two open-ended questions (See Appendix A). Students were instructed to (a) recall the instructor from the last class they were enrolled in from the spring semester and (b) complete the instruments in reference to that instructor.

Classroom Justice (see Appendix B). Perceptions of classroom distributive justice were assessed by Chory-Assad and Paulsel's (2004b) measure, containing 12 items which have shown acceptable Cronbach's reliability coefficient ranging from .69 (Chory, 2007) to .92 (Chory-Assad-Paulsel, 2004b). In this study, a Cronbach's reliability coefficient of .95 $(\mathrm{M}=46.17, \mathrm{SD}=10.97)$ was obtained for this scale. Perceptions of classroom procedural justice were assessed by Chory-Assad and Paulsel's (2004b) measure, containing 15 items which have shown acceptable Cronbach's reliability coefficient ranging from .72 (Chory, 2007) to .94 (Chory-Assad \& Paulsel, 2004b). In this study, a Cronbach's reliability coefficient of $.94(\mathrm{M}=58.01, \mathrm{SD}=12.59)$ was obtained for this scale. Perceptions of interactional justice were assessed by Chory's (2007) measure, containing 7 items which has exhibited a Cronbach's reliability coefficient of .95 (Chory, 2007). In this study, a Cronbach's reliability coefficient of $.97(\mathrm{M}=27.74, \mathrm{SD}=7.66)$ was obtained for this scale. Participants evaluated the items on the distributive, procedural, and interactional justice measures on a five-point Likert scale ranging from 1 (extremely unfair) to 5 (extremely fair).

Likelihood to Use Politeness Strategies scenario (see Appendix C). Participants were given a short scenario. In the scenario, the students are informed that their instructor returned an assignment of theirs with the grade of "F." Written on the assignment was the phrase "You received an F because you cheated. I know you wrote this paper for another class. Submitting this paper to me for this class is cheating." After reading the scenario, the participants were asked if they believed the grade received in the scenario was fair, which 
was assessed with a yes/no question. Students were then told they had a chance to speak with their instructor about their paper and were asked to answer the open-ended question, "What, if anything, would you say to your instructor about giving you an "F"?" A follow up question, which was "You would respond this way because...," was used to clarify the response to the first open-ended question.

The scenario of using the same paper for multiple classes (i.e., self-recycling plagiarism) was used because it reflected a situation that students would perceive as unfair. In his investigation of cheating behaviors, Holm (2002) used a 7-point scale to assess students perceptions of cheating $(1=$ definitely not cheating, $7=$ definitely cheating $) . \mathrm{He}$ found that of the 302 respondents, 170 respondents (56.3\%) rated "recycling a term paper" as definitely not cheating ( $n=25$ reported it as definitely cheating). Because students felt that self-recycling plagiarism was not cheating, it can be assumed that the instructor punishing students for the behavior would be perceived by the students as unfair. The present study had comparable results with $57.9 \%(\mathrm{n}=44)$ of respondents reporting on the yes/no question that they believed the grade was unfair.

\section{Data Analysis}

To code the Likelihood to Use Politeness Strategies scenario, content analysis of the open-ended questions was performed using deductive coding criteria (Frey, Botan, \& Kreps, 2000), which is appropriate for use when the research is guided by a theory that allows for $a$ priori categories to be created. The categories that were used reflected the five politeness strategies (i.e., bald-on-record, positive politeness, negative politeness, off-the-record, and forego-the-FTA) with three additional categories (i.e., "other," "I would say nothing," and left blank). The "other" category reflected participants' responses that were not specific 
enough to code. The "I would say nothing" was created to differentiate between those participants who would not challenge the grade but still perceived the grade as unfair (i.e., off-the-record) and those participants who did not challenge the instructor because they agreed with the instructor that the grade was fair which was not considered a FTA.

Two independent coders then coded the data. The coders were instructed to read the response to the first open-ended question and code it as a bald-on-record strategy, positive politeness strategy, negative politeness strategy, off-the-record strategy, forego-the-FTA strategy, other, and I would say nothing. The coding book (see Appendix D) was created using Brown and Levinson's (1987) examples for different way to enact the five politeness strategies. If the coder was unable to code the participant's response based on the first openended question, they were instructed to use the response to the second-open ended question to clarify the first open-ended question's response. Using Lombard, Snyder-Dutch, and Bracken's (2002) criteria for content analysis, the first 30 cases were coded to ascertain preliminary intercoder agreement. To assess intercoder agreement, Scott's pi (1955) was computed. Scott's $p i$ is an appropriate method to assess intercoder agreement when there are two coders and provides a more conservative estimate than Cohen's $k$ or percentile agreement (Lombard et al., 2002; Krippendorff, 2004).

Intercoder agreement for the first 30 responses was $30.2 \%$. Specifically, the rates of agreement to disagreement were as follows: bald-on-record (0/12), positive politeness (3/6), negative politeness (2/3), off-the-record (0/11), forego-the-FTA (1/0), other (1/4), and I would say nothing (5/0). Due to the low intercoder agreement, the researcher analyzed the individual responses of the two coders to ascertain what, if any, part of the coding system was responsible for the problem. Examination of the coder's responses indicated that the 
largest disagreement arose from eight responses which coder one and coder two disagreed as being an off-the-record strategy or as a bald-on-record strategy. The researcher and two coders reviewed the 30 responses and used the responses to give coder one and coder two examples of off-the-record strategies and bald-on-record strategies to ensure that the problem did not continue when they coded the final responses. The researcher and two coders then discussed each coding to establish a final code for the responses. Consensus for the final coding was achieved for all but one response, which the researcher made the final decision to code as a bald-on-record strategy.

The final 46 responses were coded using the same procedures and Scott's $p i$ was computed again with intercoder agreement of $70.4 \%$, meeting the minimum requirement of reliability. Specifically, the rates of agreement to disagreement were as follows: bald-onrecord (18/3), positive politeness (4/5), negative politeness (3/2), off-the-record (0/2), foregothe-FTA $(0 / 0)$, other $(2 / 5)$, and I would say nothing $(9 / 2)$. The researcher and two coders then discussed each coding to establish a final code for the responses. Consensus for the final coding was achieved for all responses. Scott's pi was computed for the total responses $(n=68)$, which showed intercoder agreement of $53.6 \%$.

To answer RQ1, frequency statistics were performed. To answer RQ2, RQ3, and RQ4, an analysis of variance (ANOVA) was performed to ascertain how students' perceptions of classroom justice differed based on the use of politeness strategies. For RQ2, RQ3, and RQ4 the six categories (i.e., bald-on-record, positive politeness, negative politeness, off-the-record, forego-the-FTA, and I would say nothing) from the content analysis served as the independent variable and the summed scores of distributive, procedural, and interactional justice served alternatively as the dependent variable. 


\section{CHAPTER THREE}

\section{Results}

The first research question asked about the types of politeness strategies students' use when speaking with their instructors. The results of a content analysis revealed that students use five politeness strategies with their instructors. In descending order, these strategies were bald-on-record $(n=30)$, positive politeness $(n=17)$, negative politeness $(n=7)$, off-therecord $(n=3)$, and forego-the-FTA $(n=1)$ strategy. Examples of students' use of the five politeness strategies include: bald-on record strategy (e.g., I wrote it. So it's my work not cheating; The paper is written by me anyway, so I deserve a good grade), positive politeness strategy (e.g., I'll try to write another paper and give it to him/her; I would ask if there could be an opportunity to make the grade up or if I could recieve [sic] extra credit), negative politeness strategy (e.g., Sorry, every man made [sic] a mistake, after all we are human; If I did cheat I would apologize and try to explain why), off the record strategy (e.g., How could I participate in everything and do the best I can and still fail?; If your course workload wasn't repetitive to my other classes, I woudn't [sic] even be in this situation), and forego-the FTA strategy (e.g., I wouldn't say anything). Four responses were coded as “other” (e.g., Yes, I would talk to her; Why...but it probably had good reasons). Six responses were coded as "I would say nothing” (e.g., Nothing; I would not talk because I knew it's my mistake at [sic] the first place). Eight responses were left blank by the participants. Because the forego-theFTA strategy had only one case, it was deleted from subsequent analysis as was the "other" response and blank responses.

The second research question asked in what ways, if at all, does students' perceptions of distributive justice differed based on their use of a politeness strategy when engaging in an 
FTA with their instructor. The results of an ANOVA revealed no significant differences among students' perceptions of distributive justice and their use of politeness strategies, $F$ (5, $63)=.969, p=.44$.

The third research question asked in what ways, if at all, does students' perceptions of procedural justice differed based on their use of a politeness strategy when engaging in an FTA with their instructor. The results of an ANOVA revealed no significant differences among students' perceptions of procedural justice and their use of politeness strategies, $F$ ( 5 , $63)=.43, p=.82$.

The fourth research question asked in what ways, if at all, does students' perceptions of interactional justice differed based on their use of a politeness strategy when engaging in an FTA with their instructor. The results of an ANOVA revealed no significant differences among students' perceptions of procedural justice and their use of politeness strategies, $F$ ( 5 , $63)=.77, p=.58$. 


\section{CHAPTER FOUR}

\section{Discussion}

The purpose of this study was to extend prior investigations in instructional communication utilizing politeness theory by examining how students' use of politeness strategies differed based on their perceptions of classroom justice when speaking with their instructors. This study revealed that while students report using five politeness strategies with their instructors, no differences were found in students' perceptions of the three types of justice and their use of politeness strategies when speaking with their instructors. Collectively, the results obtained in this study provide several implications for research concerning classroom justice and how students negotiate their relationship with their instructors.

The first research question inquired about the types of politeness strategies students report using with their instructors. The results indicate that students use the bald-on-record strategy the most frequently, followed by the use of the positive politeness strategy, the negative politeness strategy, the off-the-record strategy, and the forego-the-FTA strategy. Three explanations may help to explicate why students are predisposed to use less polite strategies when speaking with their instructors. The first explanation is that students may be more concerned with engaging in efficient communication with their instructors than with maintaining their instructors' face needs. The frequent use of the bald-on-record strategy seems to support this explanation as this strategy mirrors the cooperative principle (Grice, 1989). The cooperative principle states that individuals should use efficient and direct communication when speaking, which would suggest that students value the efficiency of their communication with their instructors over the face needs of their instructors. Even 
though efficiency may be a goal for students, it is important to know how this goal may affect their instructors' expectations of student-instructor communication.

One way that students' predispositions for less polite communication may affect the relationship with their instructor is by violating instructors' expectations for formality. Stephens, Houser, and Cowan (2009) suggested that instructors often have expectations for formality in face-to-face or mediated conversations. It is possible that students and their instructors differ in their goals for communicating with each other. Students' goals for efficiency could make it more likely that they would be direct in their requests for information with their instructors. Instructors may feel that students' directness violates their expectation for formality, which they may perceive as more face threatening. Therefore, instructors may want to consider that students who are direct or forthright may not intend to threaten their instructors' face, but may represent their tendency to communicate in an efficient manner. Along with instructors' consideration of their students' goals, students may want to consider the implications of their potential FTAs while using less polite strategies when speaking with their instructors.

Extant literature indicates that students' violation of their instructors' expectations for formality may lead instructors to view those students more negatively. Stephens et al. (2009) found that instructors who received more casually written, as opposed to formally written, email messages from their students felt less affect toward those students, found those students less credible, had a more negative attitude toward the message, were more bothered by the message, and were less likely to comply with the message's request. Frymier and Houser (2000) found that students reported perceived instructor use of the ego support functional communication skill was the second most important functional communication skill that 
instructors possess to be effective in the classroom. Students who communicate using less polite strategies may violate instructors' preference for formal communication, as less polite strategies are more direct. Instructors who view their students more negatively because of students' less polite communication may be less inclined to use the ego support skill, which may harm the student-instructor relationship. Frymier and Houser (2000) also found that perceived instructor use of the ego support functional communication skill was associated positively with verbal and nonverbal immediacy, student affective learning, and student state motivation, indicating that students' perceptions of a positive relationship with their instructors plays an important role in the classroom.

The second explanation is that some students may be attempting to engage in relational communication with their instructor and because of the perceived closeness (i.e., low social distance), they are less inclined to use higher order politeness strategies. Mottet and Beebe (2006) stated that students enter the classroom with the goal of instructors liking them, so students' higher reports of bald-on-record and positive politeness, as opposed to the other politeness strategies, may be because students either feel that they close enough with the instructor to be direct or are using positive politeness to cultivate solidarity with their instructor. Thus, instructors should be aware that students who use bald-on-record or positive politeness strategies when speaking with their instructors may be students who presuppose an interpersonal relationship or are attempting to form a closer relationship with their instructors. Students' attempt to form a close relationship with their instructors would be a positive finding as a close relationship may lead to students' feelings of rapport (i.e., mutual, trusting, prosocial bond between two individuals) with their instructors. Students who report rapport with their instructors also reported higher levels of classroom 
connectedness, participation, affect for content, affect toward instructor, and cognitive learning (Frisby \& Martin, 2010).

The third possible explanation for the types of politeness strategies that students report using is that some students may enact the student-as-consumer metaphor (McMillan \& Cheney, 1996). Students who perceive their relationship with their instructor from a consumer standpoint may not care to engage in politeness behaviors as they may not feel that they have an obligation to maintain their instructors' face needs. McMillan and Cheney (1996) state that students who view themselves as consumers may view the university in the same way as a fast-food restaurant, students expect the course material to be served efficiently so that they can receive the grade they want without a real investment into the university. Frymier and Houser (2000) found that students rated the referential functional communication skill (i.e., the ability to successfully relay class content) as the most important functional communication skill. Both of these studies suggest that students may feel that instructors are there to serve them by giving them the knowledge necessary to obtain the grade they want (i.e., make the customer happy). This would, in turn, reduce students' feelings of obligation to mitigate face threat to instructors as students may feel that they are entitled to efficient access to information. It is unclear whether instructors would want to assert their power to increase the imbalance of power, but instructors should be aware that students who view themselves as consumer may not view instructors as always being in a higher position of authority (McMillan \& Cheney, 1996).

The results also revealed that students' use of politeness strategies did not differ based on their perceptions of instructors' use of distributive (RQ2), procedural (RQ3), and interactional justice (RQ4). This finding indicates that students' choice of a politeness 
strategy does not change based on students' assessments of their outcomes in the class (e.g., their grade), the policies of the class, or how their instructors treat them interpersonally. There are three possible reasons why this study did not find differences in students' use of politeness strategy based on their perceptions of classroom justice. The first reason is that students' primary motive for speaking with their instructor may be more functional (i.e., learning more about assignments) than relational (i.e., seeking a personal relationship) (Martin, Myers, \& Mottet, 1999). Students who speak with their instructors for functional reasons do so to get the information necessary to receive the grade that they desire in the class. Students who are inclined to communicate for functional reasons would use the form of politeness strategy they think is best suited to get the necessary information, regardless of how fair they believe their instructor to be. If students place higher value on the functional motive than the relational motive with their instructors, then instructors should be aware that how they communicate distributive, procedural, and interactional justice may be less important than students' perceptions that they are receiving the necessary information to be successful in the classroom.

The second reason, which is also the primary limitation of this study, is that there were not enough participants to find a wide range of fair and unfair instructors. As in Chory's (2007) study, students' reports of their instructors fairness was relatively high for all three measures (i.e., distributive: $\mathrm{M}=3.85, \mathrm{SD}=.91$; procedural: $\mathrm{M}=3.87, \mathrm{SD}=.84$; interactional: $\mathrm{M}=3.96, \mathrm{SD}=1.09)$, limiting the range of potentially unfair teachers. A larger sample size may have found a wider range of fair and unfair instructors.

The third reason and another limitation of this study is that students had already received their grade for the course. Students may not feel that an instructor is unfair when 
students have received a grade that they find acceptable. Tata (1999) found that students rate their instructors higher on evaluations when they perceive their grade to be fair, which supports this reasoning. When students receive a grade that they find acceptable, they may be more inclined to find that instructor fair regardless of how their instructors communicate with them.

\section{Limitations}

In addition to addressing the issues highlighted above. The first limitation included the low intercoder agreement, which is problematic for the results of this study. Krippendorff (2004) stated that although intercoder agreement does not guarantee validity, low intercoder agreement does make the validity of the findings of the study suspect. As shown through the examination of the first and second sets of coding the responses, the coders were not adequately trained to differentiate between the five politeness strategies, especially when coding the first 30 responses. Subsequent research using this data should recode the responses using two new coders.

The second limitation was that although the majority of students found the hypothetical scenario unfair (57.9\%), the large amount of students who did not find the grade as unfair in the hypothetical scenario may have influenced the results. Students who perceive the grade as fair may have different motives for speaking with their instructor than students who perceived the grade as unfair. For example, students who believed the grade was fair may be more concerned with maintaining a good impression with their instructors, whereas those students who believed the grade was unfair may be more inclined to become more aggressive with their instructors (Sabee \& Wilson, 2005).

The third limitation was that students did not report on their classroom size. Students 
who are enrolled in a large lecture class may not have the same opportunities to form an interpersonal relationship with their instructor as students enrolled in a smaller class. They may also be more inclined to view themselves as consumers. Therefore, instructors' communication about their use of distributive, procedural, and interactional justice with their students may be perceived differently due to class size. Future research should address classroom size as a potential lurking variable (Frey, Botan, \& Kreps, 2000).

The final limitation was that students were instructed to remember an instructor from a prior semester. Although students participated in the study one or two weeks after the prior semester had ended, the time that had elapsed may have affected students' perceptions of their instructors. Despite these limitations, there are clear directions for future research as well as implications that can be drawn from the findings for instructors and students.

\section{Future Research}

A direction for future research involving politeness theory in instructional communication research includes examining how students engage in politeness with each other. Dwyer et al. (2004) established the relative lack of research focusing on studentstudent interactions and no research has been conducted to date addressing how students negotiate the face of one another in the class. Investigating how students negotiate politeness with each other could be potentially fruitful as previous research indicates that studentstudent interactions play a pivotal role in students' perceptions of being connected to the classroom environment and their own reports of in-class participation (Frisby \& Martin, 2010). Observational research would be well suited to capture the dynamic nature of how students negotiate each other's face needs. Overall, research utilizing politeness theory can guide future research examining how students and instructors negotiate the competing task 
and social goals of the classroom, which inevitably aids students in their quest to be successful both in and out of the classroom.

Future research investigating classroom justice would also aid instructors in their interactions with students. Chory-Assad (2002) established that classroom justice is a relatively untouched line of research in communication literature. Investigations in classroom justice offer researchers a great deal of new ground to break. Future areas of research should focus on the dynamic negotiation of justice through longitudinal design rather than the cross-sectional research that has been the dominant paradigm in instructional communication research. A longitudinal design also would reveal if instructors can overcome instances that students perceive as unfair across the academic semester. Knowing whether students' perceptions of instructors' fairness remain constant after a given point in the semester would aid instructors by making them aware of the times in the semester that are the most important for them to communicate their fairness in outcomes, policies, and interpersonal conversation with their students.

The present study has two pedagogical implications for instructors and students. First, because students reported using all five strategies when engaging in an FTA with their instructors, instructors should realize that students who are brusque, direct, or forthright may not perceive themselves as being disrespectful. Students may want to learn the material as efficiently as possible and move on to the next course or project, regardless of how fair the instructor attempts to be, particularly if they are not interested in establishing an interpersonal relationship with their instructors or are more concerned with receiving the grade that they want. Second, students should evaluate why they choose a particular politeness strategy when speaking with an instructor. Students' choice to engage in efficient 
communication, relational communication, or consumer-centered communication may influence how they negotiate the face needs of their instructor. 
References

Andersen, J. F. (1979). Teacher immediacy as a predictor of teaching effectiveness. Communication Yearbook, 3, 543-559.

Baxter, L. A. (1983). An investigation of compliance-gaining as politeness. Human Communication Research, 10, 427-456.

Becker, A. H., Davis, S. F., Neal, L., \& Grover, C. A. (1990). Student expectations of course and instructor. Teaching of Psychology, 17, 159-162.

Bies, S. R., \& Moag, J. S. (1986). Interactional justice: Communication criteria of fairness. Research on Negotiation in Organizations, 1, 43-55.

Brown, P, \& Levinson, S. (1978). Universals in language usage: Politeness phenomena. In E. Goody (Ed.), Questions and politeness, (pp. 56- 289). London, United Kingdom: Cambridge.

Brown, P., \& Levinson, S. (1987). Politeness: Some universals in language usage. Cambridge, UK: Cambridge University Press.

Chory, R. M. (2007). Enhancing student perceptions of fairness: The relationship between instructor credibility and classroom justice. Communication Education, 56, 89-105. doi: 10.1080./03634520600994300

Chory-Assad, R. M. (2002). Classroom justice: Perceptions of fairness as a predictor of student motivation, learning, and aggression. Communication Quarterly, 50, 58-77.

Chory-Assad, R. M., \& Paulsel, M. L. (2004a). Antisocial classroom communication: Instructor influence and interactional justice as predictors of student aggression. Communication Quarterly, 52, 98-114.

Chory-Assad, R. M., \& Paulsel, M. L. (2004b). Classroom justice: Student aggression and 
resistance as reactions to perceived unfairness. Communication Education, 53, 253273.

Colquitt, J. A. (2001). On the dimensionality of organizational justice: A construct validation of a measure. Journal of Applied Psychology, 86, 386-400.

Cropanzano, R., \& Greenberg, J. (1997). Progress in organizational justice: Tunneling through the maze. In C. L. Cooper \& I. T. Robertson (Eds.), International review of industrial and organizational psychology, (Vol. 12, pp. 317-372). London, England: John Wiley.

Dobransky, N. D., \& Frymier, A. B. (2004). Developing teacher-student relationships through out of class communication. Communication Quarterly, 52, 211_223.

Dunleavy, K., Martin, M., Brann, M., Booth-Butterfield, M., Myers, S., \& Weber, K. (2008). Student nagging behavior in the college classroom. Communication Education, 57, 119. doi:10.1080/03634520701678679

Dwyer, K. K., Bingham, S. G., Carison, R. E., Prisbell, M., Cruz, A. M., \& Fus, D. A. (2004). Communication and connectedness in the classroom: Development of the connected classroom climate inventory. Communication Research Reports, 21, 264272.

Erbert, L. A., \& Floyd, K. (2004). Affectionate expressions as face-threatening acts: Receiver assessments. Communication Studies, 55, 254-270.

Emanuel, R., \& Adams, J. (2006). Assessing college student perceptions of instructor customer service via the Quality of Instructor Service to Students (QISS) Questionnaire. Assessment \& Evaluation in Higher Education, 31, 535-549. doi:10.1080/02602930600679548. 
Finn, A., Schrodt, P., Witt, P., Elledge, N., Jernberg, K., \& Larson, L. (2009). A metaanalytical review of teacher credibility and its associations with teacher behaviors and student outcomes. Communication Education, 58, 516-537. doi:10.1080/03634520903131154

Frey, L. R., Botan, C. H., \& Kreps, G. L. (2000). Investigating communication: An introduction to research methods. Needham Heights, MA: Allyn \& Bacon.

Frisby, B. N., \& Martin, M. M. (2010). Instructor-student and student-student rapport in the classroom. Communication Education, 59, 146-164. doi:10.1080/03634520903564362

Frymier, A., \& Houser, M. (2000). The teacher student relationship as an interpersonal relationship. Communication Education, 49, 207-219.

Goffman, E. (1967). Interaction ritual: Essays on face-to-face behavior. Garden City, New York: Doubleday.

Goldsmith, D. J. (1999). Content-based resources for giving face sensitive advice in troubles talk episodes. Research on Language and Social Interaction, 32, 303-336.

Golish, T., \& Olson, L. (2000). Students' use of power in the classroom: An investigation of student power, teacher power, and teacher immediacy. Communication Quarterly, 48, 293-310.

Goodboy, A., Myers, S., \& Bolkan, S. (2010). Student motives for communicating with instructors as a function of perceived instructor misbehaviors. Communication Research Reports, 27, 11-19. doi:10.1080/08824090903526604

Grice, P. (1989). Logic and conversation. Studies in the way of words (pp. 1-138). Cambridge, Massachusetts: Harvard University. 
Holm, T. (2002). Public speaking students' perceptions of cheating. Communication Research Reports, 19, 66-76.

Holtgraves, T., \& Joong-nam, Y. (1990). Politeness as universal: Cross-cultural perceptions of request strategies and inferences based on their use. Journal of Personality and Social Psychology, 59, 719-729. doi:10.1037/0022-3514.59.4.719

Horan, S., \& Myers, S. A. (2009). An exploration of college instructors' use of classroom justice, power, and behavior alteration techniques. Communication Education, 58, 483-496. doi: 10.1080/03634520903055981

Kearney, P., Plax, T. G., \& Burroughs, N. F. (1991). An attributional analysis of college students' resistance decisions. Communication Education, 40, 325-342.

Kearney, P., Plax, T. G., Smith, V. R., \& Sorensen, G. (1988). Effects of teacher immediacy and strategy type on college student resistance to on-task demands. Communication Education, 37, 54-67.

Kerssen-Griep, J., Hess, J. A., \& Trees, A. R. (2003). Sustaining the desire to learn: Dimensions of perceived instructional facework related to student involvement and motivation to learn. Western Journal of Communication, 67, 357-381.

Kerssen-Griep, J., Trees, A. R., \& Hess, J. A. (2008). Attentive facework during instructional feedback: Key to perceiving mentorship and an optimal learning environment. Communication Education, 57, 312-332. doi: 10.1080/03634520802027347

Krippendorff, K. (2004). Content analysis: An introduction to its methodology. Thousand Oaks, California: Sage.

Lim, T. \& Bowers, J. W. (1991). Facework: solidarity, approbation , and tact. Human Communication Research, 17, 415-450. 
Lombard, M., Snyder-Duch, J., \& Bracken, C. C. (2002). Content analysis in mass communication: Assessment and reporting of intercoder reliability. Human Communication Research, 28, 587-604. doi: 10.1111/j.1468-2958.2002.tb00826.x

Martin, M. M., Myers, S.A., \& Mottet, T. P. (1999). Students' motives for communicating with their instructors. Communication Education, 48, 155-164.

McCroskey, J. C., \& Teven, J. J. (1999). Goodwill: A reexamination of the construct and its measurement. Communication Monographs, 66, 90-103.

McMillan, J., \& Cheney, G. (1996). The student as consumer: The implications and limitations of a metaphor. Communication Education, 45, 1-15.

Mottet, T. P., \& Beebe, S. A. (2006). Foundations of instructional communication. In T. P. Mottet, V. P. Richmond, \& J. C. McCroskey (Eds.), Instructional communication: Rhetorical and relational perspectives (pp. 3-32). Boston, Massachusetts: Allyn \& Bacon.

Mottet, T. P., Parker-Raley, J., Cunningham, C., Beebe, S. A., \& Raffeld, P. C. (2006). Testing the neutralizing effect of instructor immediacy on student course workload expectancy violations and tolerance for instructor unavailability. Communication Education, 55, 147-166. doi:10.1080/03634520600565886

Myers, S. A., \& Rocca, K. A. (2001). Perceived instructor argumentativeness and verbal aggressiveness in the college classroom: Effects on student perceptions of climate, apprehension, and state motivation. Western Journal of Communication, 65, 113-137.

Nussbaum, J. F. \& Scott, M. D. (1979). Instructor communication behaviors and their relationship to classroom learning. Communication Yearbook, 3, 561-583.

Paulsel, M. L., \& Chory-Assad, R. M. (2005). Perceptions of instructor interactional justice 
as a predictor of student resistance. Communication Research Reports, 22, 283-291. doi: $10.1080 / 000368105000317565$

Paulsel, M. L., Chory-Assad, R. M., Dunleavy, K. N. (2005). The relationship between student perceptions of instructor power and classroom justice. Communication Research Reports, 22, 207-215. doi: 10.1080/00036810500207030

Plax, T., Kearney, P., \& Tucker, L. (1986). Prospective teachers use of behavior alteration techniques on common student misbehaviors. Communication Education, 35, 32-42.

Sabee, C., \& Wilson, S. (2005). Students' primary Goals, attributions, and facework during conversations about disappointing grades. Communication Education, 54, 185-204. doi:10.1080/03634520500356154.

Stephens, K. K., Houser, M. L., Cowan, R. L. (2009). R U able to meat me: The impact of students' overly casual email messages to instructors. Communication Education, 48, 303-326. doi: 10.1080/03634520802582598

Tata, J. (1999). Grade distributions, grading procedures, and students' evaluations of instructors: A justice perspective. The Journal of Psychology, 133, 263-271.

Teven, J., \& McCroskey, J. (1997). The relationship of perceived teacher caring with student learning and teacher evaluation. Communication Education, 46, 1-9.

Tracy, K., \& Tracy, S. J. (1998). Rudeness at 911: Reconceptualizing face and face attack. Human Communication Research, 25, 225-251.

Trees, A. R., Kerssen-Griep, J., \& Hess, J. A. (2009). Earning influence by communicating respect: Facework's contributions to effective instructional feedback. Communication Education, 58, 397-416. doi: 10.1080/03634520802613419

Wilson, S. R., Aleman, C. G., \& Leatham, G. B. (1998). Identity implications of influence 
goals: A revised analysis of face-threatening acts and application to seeking compliance with same-sex friends. Human Communication Research, 25, 64-96. doi: 10.1111/j.1468-2958.1998tb00437.x 
Appendix A

\section{WestVirginiaUniversity}

\section{Department of Communication Studies}

April 20, 2010

Dear Participant:

You are being asked to participate in a study conducted by Principal Investigator Dr. Scott Myers and Co-Investigator Charles Rudick in the Department of Communication Studies at West Virginia University. The purpose of this study is to conduct professional research. This research is interested in your how you perceive your instructors' fairness the classroom and how you communicate with them because of it. Participating in the self-report survey indicates that you have agreed to participate in this study. To participate in this study, you must be at least 18 years old and currently be enrolled full time at WVU.

Do not put your name on this survey to ensure anonymity. We ask you to complete the questionnaire and respond freely and honestly to all questions posed. The researchers in this study will keep your answers anonymous, which means no one will be able to associate your responses with you. The questionnaires will be securely kept and destroyed at the end of the study (approximately 1 year from today).

Participation in this study is voluntary. You may skip certain questions if you want and you may stop at any time without fear of penalty. If you are a student, your actual performance in this study, your refusal to participate, or withdrawal from this study will in no way affect your class standing, grades, job status, or status in any athletic or other activity associated with West Virginia University. There are no known risks associated with participation in this study. It should take approximately 20 minutes to complete.

If you would like more information about this research project, feel free to contact the Principal Investigator Dr. Myers or Co-Investigator Charles Rudick at 304-293-3905 or by email. This study has been acknowledged by West Virginia University's Institutional Review Board.

Thank you for your participation.

Sincerely,

Dr. Scott A. Myers

Professor

Principal Investigator

Scott.myers@mail.wvu.edu
Charles K. Rudick

M. A. Student

Co-Investigator

crudick@mix.wvu.edu 
Appendix A (continued)

Please fill in your responses based on the instructor you had for the last class you took in the previous spring semester.

Identify this course by its subject matter (e.g. Biology, Math, Psychology)

What is the sex of THE INSTRUCTOR? Please circle:

MALE

FEMALE

Please write THE INITIALS of the instructor.

DIRECTIONS: Below are several descriptors of how fair you think your instructor is in general. Please use the scale below to rate the degree to which you feel each statement applies from 1 (extremely unfair) to 5 (extremely fair).

$1 \quad 2 \quad 3 \quad 4 \quad 5$

Extremely Unfair Slightly Unfair Neither Fair nor Unfair Slightly Fair Extremely Fair

Using the ratings listed above, please rate the fairness of the instructor of the last class you took in the previous spring semester about your grade on the last exam compared to...

1. Other students' grades on the exam.

2. The grade you expected to receive on the exam.

3. The effort you put into studying for the exam.

4. The grade(s) you received on other exams in this course.

5. The grade most other students at this university would have received on the exam.

Using the same rating system, please rate the fairness of the instructor of the last class you took in the previous spring semester about the grade you received in this course compared to...

6. The grades other students in the course received.

7. The grade you expected to receive in this course at the beginning of the semester.

8. The grade you felt you deserved to receive in this course.

9. The grade(s) you received in similar courses. 
Appendix A (continued)

10.The grade most other students at this university would have received in this course.

11. Your grade on the last exam.

12. The grade you received in this course.

DIRECTIONS: Below are several descriptors of how fair you think your instructor is in general. Please use the scale below to rate the degree to which you feel each statement applies from 1 (extremely unfair) to 5 (extremely fair).

$\begin{array}{lllll}1 & 2 & 3 & 4 & 5\end{array}$

Extremely Unfair Slightly Unfair Neither Fair nor Unfair Slightly Fair Extremely Fair

Using the ratings listed above, please rate the fairness of the instructor of the last class you took in the previous spring semester about ...

13. The missed work make-up policies.

14. The course attendance policies.

15. The grading scale for the course

16. The course's schedule of topics.

17. How the instructor conducted class discussions.

18. The way the instructor called on students in class.

19. The way the instructor conducted class.

20. The course syllabus.

21. The scheduling of exams.

22. The instructor's expectation of students.

23. The types of questions on exams.

24. The amount of work required to get a good grade in the course.

25. The number of questions on exams.

26. The level of difficulty of the course content. 
Appendix A (continued)

27. The scheduling of homework and other written assignments.

Using the same rating system, please rate the fairness of the instructor of the last class you took in the previous spring semester about ...

28. The way the instructor treated students.

29. The instructor's communication with students.

DIRECTIONS: Below are several descriptors of how fair you think your instructor is in general. Please use the scale below to rate the degree to which you feel each statement applies from 1 (extremely unfair) to 5 (extremely fair).

$1 \quad 2 \quad 3 \quad 4 \quad 5$

Extremely Unfair Slightly Unfair Neither Fair nor Unfair Slightly Fair Extremely Fair

Using the ratings listed above, please rate the fairness of the instructor of the last class you took in the previous spring semester about ...

30. The way the instructor listened to students.

31. The way the instructor dealt with students.

32. The way the instructor talked to students.

33. How the instructor considered students' opinions.

34. How the instructor handled students who disagreed with him/her.

DIRECTIONS: Please complete the following demographic information.

1. Age:

2. Ethnicity (please circle one): American Indian

Asian/Eastern Pacific

Black/African American

Caucasian 
Appendix A (continued)

Latino/a

Middle Eastern

Other:

3. Please check your year in school:

First year __ Sophomore ___ Junior ___ Senior ___ Other _

4. Please circle your sex: MALE FEMALE 
Appendix B

Classroom Justice Scales

\section{Distributive Justice}

\section{Your grade on the last exam compared to...}

1. Other students' grades on the exam.

2. The grade you expected to receive on the exam.

3. The effort you put into studying for the exam.

4. The grade(s) you received on other exams in this course.

5. The grade most other students at this university would have received on the exam.

6. The grades other students in the course will probably receive.

\section{The grade you will probably receive in this course compared to...}

7. The grade you expected to receive in this course at the beginning of the semester.

8. The he grade you feel you deserve to receive in this course.

9. The grade(s) you've received in similar courses.

10. The grade most other students at this university would receive in this course.

11. Your grade on the last exam.

12. The grade you will probably receive in this course.

\section{Procedural Justice}

1. The missed work make-up policies.

2. The course attendance policies.

3. The grading scale for the course

4. The course's schedule of topics. 
Appendix B (continued)

5. How the instructor conducts class discussions.

6. The way the instructor calls on students in class.

7. The way the instructor conducts class.

8. The course syllabus.

9. The scheduling of exams.

10. The instructor's expectations of students.

11. The types of questions on exams.

12. The amount of work required to get a good grade in the course.

13. The number of questions on exams.

14. The level of difficulty of the course content.

15. The scheduling of homework and other written assignments.

\section{Interactional Justice}

1. The way the instructor treats students.

2. The instructor's communication with students.

3. The way the instructor listens to students.

4. The way the instructor deals with students.

5. The way the instructor talks to students.

6. How the instructor considers students' opinions.

7. How the instructor handles students who disagree with him/her.

* Participants rated the fairness of the above statements on a five-point Likert scale with responses ranging from 1 (extremely unfair) to 5 (extremely fair). 
Appendix C

Likelihood to Use Politeness Strategies scenario

DIRECTIONS: Imagine the following situation occurred with the instructor of the last class you took in the previous spring semester. At the beginning of class, your instructor hands you back a paper with a grade of "F" and the phrase "You received an F because you cheated. I know you wrote this paper for another class. Submitting this paper to me for this class is cheating." 
Rate 1-7 according to the criteria below:

\section{Appendix D}

1. Bald-on-record: Does the student:

Attempt to be direct, forthright, or blunt?

Attempt to minimize vagueness of the student's position?

Seem to value the honesty of the message over the need for politeness?

2. Positive Politeness- Does the student:

Notice/attend to the instructor's interests, wants, needs?

Show sympathy for the instructors' position?

Use in-group identity markers?

Claim common ground or knowledge?

Indicate that the instructor tried to take the student's wants into account?

Barter for the grade?

Give or ask for reasons?

Assume reciprocity?

Give gifts?

3. Negative Politeness- Does the student:

Minimize the imposition of the challenge?

Give deference to the instructor's title?

Make apologies?

Make the clash more general or abstract (e.g., instead of I/you, the student talks about a hypothetical person with the same problem)

Go on record as incurring a debt?

4. Off Record Strategy- Does the student:

Give hints as a challenge to the grade?

Understate or overstate the magnitude of the challenge?

Use contradictions, irony, metaphors, or rhetorical questions?

Attempt to be intentionally vague?

5. Forego-the-FTA: Does the student:

Say that they know the grade is unfair, but would rather not confront their instructor about it?

6. Other: The material is not specific enough to be coded.

7. I would say nothing- Does the student: 
Agree that the grade is fair and says that they wouldn't challenge the grade?

John H.

Hagen 